\title{
APOE4 Protects the Cognitive Development in Children with Heavy Diarrhea Burdens in Northeast Brazil
}

\author{
REINALDO B. ORIÁ, PETER D. PATRICK, HONG ZHANG, BREYETTE LORNTZ, \\ CARLOS MAURÍCIO DE CASTRO COSTA, GERLY A.C. BRITO, LEAH J. BARRETT, \\ ALDO A.M. LIMA, AND RICHARD L. GUERRANT \\ Center for Global Health [R.B.O, H.Z, B.L., L.J.B., R.L.G.], School of Medicine, Kluge's Children \\ Rehabilitation Center [P.D.P], University of Virginia, Charlottesville, Virginia 22908, Department of \\ Physiology and Pharmacology [C.M.C.C.], Department of Morphology [G.A.C.B.], Institute of \\ Biomedicine and Clinical Research Unit-University Hospital [A.A.M.L], Federal University of Ceará, \\ CEP 60.435-160, Fortaleza-Ce, Brazil, University of Fortaleza [R.B.O.], Edson Queiroz, CEP 60.811-905, \\ Fortaleza-Ce, Brazil.
}

\begin{abstract}
ABST
Polymorphisms in the apolipoprotein E (APOE) have consti-
tuted the major rationale to identify potential risk groups for devel-
oping late-onset Alzheimer's disease and help to predict recovery of
cognitive function after brain injury. However, the APOE impact on
cognitive development in children living in poor areas of the devel-
oping world, where we have discovered profound significant asso-
ciations of early childhood diarrhea (at $0-2$ y) with lasting impair-
ments of growth, cognition, and school performance, is not known.
Therefore, we conducted APOE genotyping in 72 Brazilian shan-
tytown children under active surveillance since birth, using purified
DNA extracted from buccal cell samples. We found a high fre-
quency of APOE4 alleles (18\% versus $9-11 \%$ expected) in children
with lower diarrhea burdens. When we examined the children who
experienced the heavier diarrhea burdens (greater than or equal to
the median of seven illnesses in the first 2 y of life), those with
APOE4 did significantly better in the coding subtest ( $p=0.01$ )
when compared with APOE4-negative children with similar diar-
rhea burdens. Positive correlations between the APOE4 occurrence
and coding scores remained, even after adjusting for family income,
\end{abstract}
Polymorphisms in APOE have been associated with poor outcomes after brain injury $(1,2)$ and have constituted the major rationale to identify potential risk groups for developing

Received January 15, 2004; accepted June 7, 2004.

Correspondence: Richard L. Guerrant, M.D., Center for Global Health, School of Medicine, University of Virginia, MR4, Lane Rd., Room 3148, Charlottesville, VA 22908; e-mail: rlg9a@ virginia.edu

Supported in part by National Institutes of Health ICDR Grant no. 5-UOI AI 26512-14, ABC Grant no. 5D43 TW01136-04 and in part by TMRC Grant no.5 P50 AI30369-09 and Grant no. TW000909-05.

R.B.O. and G.A.C.B. were recipients of Fogarty International Center ABC (Actions for Building Capacity) research fellowships and H.Z. was a Fogarty Center ITREID (International Training in Research in Emerging Infectious Diseases) research fellow.

DOI: 10.1203/01.PDR.0000148719.82468.CA maternal education, and breast-feeding. Moreover, the APOE4positive group, under heavy burdens of diarrhea, had preserved semantic fluency and the mean difference in fluency scores, $p=$ 0.025 , a standardized coefficient for disproportional verbal fluency impairment. Our findings show that APOE4 is relatively common in favela children and suggest a protective role of the APOE4 allele in children with a history of heavy burdens of diarrhea in their first $2 \mathrm{y}$ of life. (Pediatr Res 57: 310-316, 2005)

$\quad$ Abbreviations
APOE, apolipoprotein E gene
apoE, apolipoprotein E protein
DIFF, mean difference in fluency scores
ECD, early childhood diarrhea
HAZ, height-for-age z score
TG, triglycerides
WAZ, weight-for-age z score
WHZ, weight-for-height z score
WISC-III, Wechsler Intelligence Scale for Children

late-onset Alzheimer's disease $(3,4)$. However, little is known about how genetic markers such as APOE alleles influence the injurious effects of diarrheal illnesses on brain maturation.

Cognitive function in children is affected by environment, genetic determinants, and health-related factors. Risk factors that interfere with cognitive function are especially important during infancy because the first $2 \mathrm{y}$ of life are an essential period of rapid growth and development.

In impoverished settings, children experiencing repeated diarrheal illnesses and malabsorption in their first years of life may have significant cognitive impairment $(5,6)$. Malnutrition impairs brain development by decreasing the number of cell replication cycles (7), reducing total brain DNA (8), and 
restricting dendritic arborization (9), thus reducing connections between neurons. Synaptic connectivity is particularly affected if nutritional deprivation occurs between birth and the third year of life (10). Alteration in dietary precursors may affect tissue levels of neurotransmitters (serotonin, norepinephrine, dopamine, and acetylcholine) in specific brain regions $(11,12)$. Essential and nonessential lipid supplies affect the structural composition of the brain and of myelin sheaths. Furthermore, functional outcomes correlate with these biochemical changes induced by malnutrition, as evidenced by alterations in the waking EEG activity and in visual and auditory evoked responses; motor and cognitive development, and social abilities (12,13).

Our group has documented that ECD illnesses and enteric infections are associated with profound effects on later physical and cognitive development (14-18). Recently, Peruvian studies have also demonstrated the association of shortfalls in intellectual functioning with early linear growth declines after ECD illnesses $(19,20)$.

It has been demonstrated that there is no association between apolipoprotein E polymorphisms and general cognitive ability in healthy children (21). However, the APOE impact on cognitive development in children living in poor areas of the developing world, where we have discovered profound significant associations of early childhood diarrhea (at 0-2 y) with lasting impairments of growth, cognition, and school performance, is not known. Therefore, based on our previous findings, we have conducted APOE genotyping in 72 Brazilian shantytown cohort children under active surveillance since birth to evaluate the APOE influence on cognitive development in children challenged by heavy burdens of early childhood diarrhea.

\section{METHODS}

Population. The study was conducted at Gonçalves Dias (population approximately 1800), a shantytown (favela) located in Fortaleza (population estimated at 2.1 million), capital city of the state of Ceará (population approximately 6 million) in Northeast Brazil. The Gonçalves Dias community has been described in greater detail elsewhere (16). The characteristics of the study population enrolling 72 Brazilian children were addressed longitudinally, as a part of ongoing prospective surveillance of a cohort children followed from birth. We have used the World Health Organization (WHO) guidelines to recognize an episode of diarrhea, as described by Moore and colleagues (17). One episode of diarrhea was defined as the excretion of three or more liquid or semiliquid stools in a 24 -h period. A new episode was defined by a $\geq 48$-h period not meeting the diarrhea definition. Recurrent and persistent episodes of diarrhea in this setting have been most significantly associated with Cryposporidium, Giardia, and enteroaggregative Escherichia coli infections (16). The mean number of diarrhea episodes in their first $2 \mathrm{y}$ of life was $9.2( \pm 6.9)$; only $25.0 \%$ of the mothers had completed primary schooling. Human Investigation Committees at both the University of Virginia and at the Federal University of Ceará approved the study protocol. The parent/legal guardian of the eligible children was approached by the study investigator or delegate (nurse of the field team) to explain the study. If they agreed, together they read and signed the approved consent form. Each child was screened for head circumference and height and was observed to be medically stable and engaged in community and academic activities. These children were administered three psychometric exams that are sensitive to components of executive function. Each child received a language-free, culturally neutral IQ examination using the Test of Nonverbal Intelligence III (TONI-3, Pro-Ed, Austin, TX).

Anthropometric measurements. The field team measured the length and weight of study children. Length was measured supine to the nearest $0.1 \mathrm{~cm}$ with a measuring board. Length measurements were converted to HAZ, weight was converted to WAZ, and both indicators were converted to WHA, using anthropometric software (Epi Info, Centers for Disease Control, Atlanta, GA). These anthropometric $\mathrm{z}$ scores are the number of SD above or below the median values for the National Center for Health Statistics (NCHS) and International Reference Population, described elsewhere (22). A questionnaire was provided to assess socioeconomic and demographic data.

The supine length measurement of occipitofrontal head circumference was conducted as described by Zemel et al. (23), with the assumption that the shape of the head is determined during the early months of life.

Buccal cell collection (toothbrush-rinse method). Each child was enrolled individually by a trained health worker (well known to the children), who conducted the sample collection. The health worker asked each child to gently swish and swallow $20 \mathrm{~mL}$ of drinking water to reduce food particles. The subject then dipped a sterile soft cytobrush in a cup containing $10 \mathrm{~mL}$ of drinking water to soften the bristles, brushing the buccal surface 10 times (one upstroke and one downstroke) and then expectorating the saliva into the $50-\mathrm{mL}$ sterile polypropylene centrifuge tube, repeating the process in the opposite side of the cheek. Afterward, the subject swished $10-\mathrm{mL}$ of water for $45 \mathrm{~s}$, with the health worker timing, and expectorated into the same $50-\mathrm{mL}$ tube. In the end, the technician slowly poured $5 \mathrm{~mL}$ of $99 \%$ ethanol over the bristles of the cytobrush into the same $50-\mathrm{mL}$ tube to prevent bacterial overgrowth, and delivered it to the laboratory for processing within $4 \mathrm{~h}$.

DNA extraction. The DNA from buccal cell samples was isolated using a modification of a Gendra Puregene protocol (Gendra System, Minneapolis, $\mathrm{MN}$ ), after steps of cell lysis, RNAse treatment, protein precipitation, DNA precipitation, and DNA hydration as described by London et al. (24).

APOE genotyping. The experimental protocol involved an amplification of APOE sequences from genomic DNA and digestion by the action of HhaI restriction enzyme first described by Hixson and Vernier (25).

DNA from buccal cells was purified and then amplified by PCR in a thermal cycler using oligonucleotide primers F4 (5'-GCACGGCTGCCAAGGAGCTGCAGGC-3') and F6 (5'-GGCGCTCGCGGATGGCGCTGAG-3'), according to a protocol described by Addya et al. (26). In addition to the buffer, nucleotide components and $2.5 \mathrm{U}$ of Taq polymerase described by the supplier of PCR master mix (Roche Molecular Biochemicals, Indianapolis, IN), each amplification reaction contains $1 \mu \mathrm{g}$ of buccal cell DNA, $1-2 \mu \mathrm{M}$ of each primer, and $10 \%$ DMSO in a final volume of $50 \mu \mathrm{L}$. The PCR condition included an initial step of $95^{\circ} \mathrm{C}$ for $4 \mathrm{~min} ; 62^{\circ} \mathrm{C}, 30 \mathrm{~s} ; 72^{\circ} \mathrm{C}, 1 \mathrm{~min}$, followed by 39 cycles $\left(95^{\circ} \mathrm{C}, 15 \mathrm{~s} ; 62^{\circ} \mathrm{C}, 15 \mathrm{~s} ; 70^{\circ} \mathrm{C}, 15 \mathrm{~s}\right)$, and by a final extension $\left(72^{\circ} \mathrm{C}, 3 \mathrm{~min}\right.$ ) with a $4^{\circ} \mathrm{C}$ hold. The uncut amplification products, $10 \mu \mathrm{L}$ out of the $50 \mu \mathrm{L}$ PCR product, were electrophoresed in a $2 \%$ Ultrapure agarose gel (Invitrogen, Carlsbad, CA), containing $0.4 \mu \mathrm{g} / \mathrm{mL}$ ethidium bromide and $1.0 \times$ TAE (Tris-acetate-EDTA).

After PCR amplification, 5 units of HhaI (New England BioLabs, Beverly, MA) were added directly to each reaction mixture for digestion of APOE sequences $\left(3 \mathrm{~h}\right.$ at $\left.37^{\circ} \mathrm{C}\right)$. This process does not require purification of PCR products or addition of specific buffer components for HhaI. Each reaction mixture was loaded onto a $4 \%$ gel agarose (3\% Nursuive GTG gel $+1 \%$ Ultrapure gel), containing $0.4 \mu \mathrm{g}$ ethidium bromide in $0.5 \times \mathrm{TBE}$ (Tris-borateEDTA) and electrophoresed for $1 \mathrm{~h}$ under constant voltage (100 V). The gel was cast on a $10 \times 15 \mathrm{~cm}$ tray. After electrophoresis, digested fragments were visualized by UV illumination. The sizes of HhaI fragments were estimated by comparison with known DNA ladders. Some samples were also sent for DNA sequencing and further genotype confirmation by analyzing the purified PCR product (Qia-Quick PCR Purification Kit, QIAGEN, Valencia, CA), generated by forward primer, described by Hixson and Vernier (25).

Cognitive tests. The battery of tests was conducted in a standardized manner with instructions given in Portuguese in a quiet room by a trained health worker assisted by a neuropsychologist. They included three subtests: verbal fluency, coding, and Elithorn mazes. All cognitive tests were applied blindly with regard to the information of children's diarrhea histories. The verbal fluency tests were applied according to the NEPSY Developmental Neuropsychological Assessment booklet (The Psychological Corporation, San Antonio, TX), evaluating the ability to generate words in semantic categories and phonetic constraints. The semantic test required the children to say as many animal and then food names as possible in 1-min periods. The phonetic test required children to name words that start with $\mathrm{F}$ and then with $\mathrm{S}$ in 1-min trials. The total score was obtained by the number of words said, excluding proper names and avoiding words that do not belong to the category requested, nonsense words, and repetitions, mainly words in plural, different tenses, and 
diminutive forms. In the coding test, paired associated symbol recall (age 8-16 y) was administered according to the standard WISC-III (The Psychological Corporation) to evaluate visual short-term memory. The child was required to remember symbols associated with specific digits and to draw the corresponding symbol for each digit. The coding subtest scores the total number of errors in a 120-s trial and the number of correctly drawn symbols at each 30-s interval. The child was awarded with 1 point for each correctly drawn symbol. The total raw score was converted to a scaled score, according to the WISC-III record form. Elithorn mazes (age 8-16 y) designed by the WISC-III were administered by closely examining the child's ability to plan ahead and to inhibit impulsive responses. For each maze, the child was asked to draw a path through a specified number of dots to an exit at the top of the maze. Motor skills were analyzed considering motor planning on two trials, within $120 \mathrm{~s}$ for trial 1 and $60 \mathrm{~s}$ for trial 2 (administered only if trial 1 was failed within the first $60 \mathrm{~s}$ ). The total subtest raw score was the sum of the earned points by the different criteria within the time limit, deducting points for wrong starts, failures to pass through a specified number of dots, cuts across interpassage lines, or going in an imprecise direction.

Statistics. The data were analyzed with the SPSS statistical software package (SPSS, Inc, Chicago, IL) and GraphPad Prism software version 3.00 for Windows (San Diego, CA). allelic frequencies were determined by counting different alleles and calculating their proportions. Demographic characteristics were described in terms of rates and percentages. Likelihood ratio analysis of contingency table was used in the investigation of categorical variables (e.g. frequency of the different alleles among cohort children). Measurements of association among categorical variables were done using $\chi^{2}$ contingency tables, corrected by Mantel-Haenszel or Fisher exact test, and to verify whether the observed allele frequencies agreed with those expected, frequencies were input to confirm the hypothesis of Hardy-Weinberg (H-W) equilibrium, using a $\chi^{2}$ goodness-of-fit test. Multilinear regression and correlation analyses were performed to avoid other potential confounders, controlling for malnutrition indicators, socioeconomic status, mother educational level, and intestinal parasites. Student's unpaired $t$ test was used for continuous terms.

\section{RESULTS}

DNA purification and APOE genotyping. The toothbrushrinse method used for collecting buccal cell DNA was suitable to field routine and well accepted by the children. The mean DNA yield $(2.27 \pm 2.45 \mu \mathrm{g})$ and $260 / 280$ purity ratio $(1.41 \pm$ 0.35 ) obtained from 72 study samples provided high success rates for PCR amplification and restriction digestion.

Demographics. The characteristics of cohort children according to APOE4 distribution are shown in Table 1. Mean values for all anthropometric variables and social backgrounds were similar between APOE4-positive children (who harbor genotypes 2/4, $3 / 4$, or $4 / 4$ ) and APOE4-negative children (who harbor genotypes $2 / 3,2 / 2$, or $3 / 3$ ). The allelic and genotype distributions in the whole study population are depicted in Table 2 . There was no statistical deviation from $\mathrm{H}-\mathrm{W}$ equilibrium. The frequency of the allele $\epsilon 4(14.6 \%)$ was slightly higher in our cohort shantytown children when compared with expected $9-12 \%$ in general Brazilian population described recently in different surveys (27-29). However, when we divided the cohort children in two different groups, according to burdens of diarrhea in their first years of life, as seen in Table 2, the frequency of the allele 4 was even higher in the group with lower diarrhea episodes (less than the mean episodes of diarrhea in all children), $17.5 \%$, when compared with neighborhood children with heavier burdens of diarrhea (more than the mean episodes of diarrhea of the whole population), $10.8 \%$. In addition, the mean number of episodes of infantile diarrhea in $\epsilon 4$ carriers $(8.2 \pm 1.8, n=21)$ was significantly lower $(p<0.001)$ when compared with noncarriers of $\epsilon 4$ alleles $(9.7 \pm$ $0.9, n=51$ ). It is noteworthy that the APOE4-positive group did not show the positive correlation $(n=17, r=0.16, p=0.53)$ between Giardia lamblia infection and episodes of diarrhea observed in the non-APOE4 carriers $(n=36, r=0.42, p=0.01)$.

Cognitive tests. Unexpectedly, APOE4-negative children did not exhibit enhanced scores in all cognitive tests examined. Indeed, APOE4-positive children showed a trend of a better

Table 1. Demographics and anthropometrics of the study population according to APOE4 alleles

\begin{tabular}{|c|c|c|}
\hline \multirow[b]{2}{*}{ Cohort characteristics } & \multicolumn{2}{|c|}{ Cohort children } \\
\hline & $\operatorname{APOE} 4(+)$ & APOE4(-) \\
\hline Mean age $(y)$ & $10.1 \pm 1.6$ & $9.52 \pm 1.7$ \\
\hline Head circumference & $54.2 \pm 1.8(n=21)$ & $53.51 \pm 2.1(n=47)$ \\
\hline Birth weight (g) & $3434 \pm 478(n=17)$ & $3255 \pm 431(n=38)$ \\
\hline \multicolumn{3}{|l|}{ Sex } \\
\hline Female & $15(71 \%)$ & $29(57 \%)$ \\
\hline Male & $06(29 \%)$ & $22(43 \%)$ \\
\hline \multicolumn{3}{|l|}{ Nutritional status at 2 y old $*$} \\
\hline HAZ 0 & $-0.01 \pm 0.9(n=21)$ & $-0.20 \pm 1.84(n=49)$ \\
\hline HAZ 24 & $-1.14 \pm 1.48(n=20)$ & $-0.90 \pm 1.126(n=44)$ \\
\hline WAZ 0 & $0.42 \pm 1.2(n=21)$ & $0.003 \pm 0.94(n=49)$ \\
\hline WAZ 24 & $-0.78 \pm 1.23(n=20)$ & $-0.46 \pm 1.01(n=44)$ \\
\hline WHZ 0 & $1.92 \pm 4.07(n=21)$ & $4.20 \pm 5.07(n=49)$ \\
\hline WHZ 24 & $-0.04 \pm 1.44(n=20)$ & $0.08 \pm 0.90(n=44)$ \\
\hline Mean diarrhea episodes & $8.2 \pm 1.8 \S(n=21)$ & $9.7 \pm 0.9(n=51)$ \\
\hline \multicolumn{3}{|l|}{ Maternal education } \\
\hline Below primary school & $15(71 \%)$ & $35(69 \%)$ \\
\hline Primary school or above & $6(29 \%)$ & $11(21 \%)$ \\
\hline Unknown & - & $5(10 \%)$ \\
\hline \multicolumn{3}{|c|}{ Monthly income** minimum salary } \\
\hline$<2$ & $9(43 \%)$ & $22(43 \%)$ \\
\hline$\geq 2$ & $7(33 \%)$ & $9(18 \%)$ \\
\hline Unknown & $5(24 \%)$ & $20(39 \%)$ \\
\hline
\end{tabular}

* HAZ, WAZ, and WHZ at birth (0) and at 1 y old (24).

** 1 minimum wage: US $\$ 102 /$ month.

$\S p<0.001$, by unpaired student $t$ test. 
Table 2. ApoE genotype and allele frequencies (f) of cohort children (6-12 y) with different burdens of diarrhea in Gonçalves Dias (GD) shantytown, Fortaleza, northeast of Brazil $(\mathrm{n}=72)$

\begin{tabular}{|c|c|c|c|c|c|c|c|c|c|}
\hline \multirow[b]{2}{*}{ APOE } & \multicolumn{6}{|c|}{ Genotypes } & \multicolumn{3}{|c|}{ Alleles } \\
\hline & $2 / 2$ & $2 / 3$ & $3 / 3$ & $2 / 4$ & $3 / 4$ & $4 / 4$ & 2 & 3 & 4 \\
\hline Group $1, n(f \%)$ & $01(3.12)$ & 03 (9.37) & $21(65.63)$ & $02(6.25)$ & 05 (15.63) & $00(00)$ & 07 (10.9) & $50(78.2)$ & 07 (10.9) \\
\hline Total, $n(f \%)$ & $01(1.4)$ & 08 (11.1) & $42(58.3)$ & $02(2.8)$ & $19(26.4)$ & $00(00)$ & $12(8.3)$ & $111(77.1)$ & 21 (14.6) \\
\hline
\end{tabular}

Group 1, cohort children with $\geq$ the mean episodes of diarrhea $(n=32)$; group 2, cohort children with $<$ the mean episodes of diarrhea $(n=40)$. Mean episodes of diarrhea in the first $2 \mathrm{y}$ of life $=9.28$.

performance in all cognitive assessments, albeit not reaching statistical significance. Moreover, when we examined the children who experienced the heavier diarrhea burdens (greater than or equal to the median of seven illnesses in the first $2 \mathrm{y}$ of life), those with APOE4 did significantly better in the coding subtest $(p=$ 0.01) when compared with APOE4-negative children (Fig. 1a). In addition, we found a positive correlation between the occurrence of the $\epsilon 4$ allele and the coding scores $(r=0.295, p=0.01)$. The $\epsilon 4$ remained a good predictor of coding scores, even after adjusting for family income, maternal education $(\beta=0.303, p<0.05)$ and breast-feeding $(\beta=0.275, p=0.03)$.

Furthermore, we found the APOE4-positive children had preserved semantic fluency, despite heavy burdens of diarrhea, which profoundly impaired semantic fluency in the APOE4-negative children, $p<0.01$. In addition, the mean difference in fluency scores $($ DIFF $=$ phonetic - semantic scores), a standardized coefficient for verbal fluency disproportional impairment, described by Cerhan et al. (30), was also preserved in the APOE4positive children, despite heavy diarrhea burdens, $p<0.03$ (Fig. $1, b$ and $c$ ). APOE4-positive children with heavy diarrhea burdens had higher total verbal fluency, as well $(p<0.05)$.

Genotypes and allele frequencies according to cognitive scores are shown in Table 3. As also highlighted in Table 3, the frequency of allele 4 was higher $\left(\chi^{2}=4.34, p<0.04\right)$ in the cohort children with higher TONI III scores (greater than the median of the test scores), but it was not sufficient to explain a statistical difference between APOE4-positive and -negative children in the whole population in regard to IQ mean scores. However, under heavy burdens of diarrhea (greater than or equal to the median of seven illnesses in the first $2 \mathrm{y}$ of life), the high frequency of allele $4\left(\chi^{2}=7.69\right.$, $p=0.01$ ) in children with higher coding scores (greater than the median of the test scores), matched well with the better coding test scores of APOE4-positive children in comparison with cohort children not possessing the allele 4 , as shown in Table 3 and Figure $1 a$.

\section{DISCUSSION}

Apolipoprotein E has a major physiologic role in the regulation of overall lipid homeostasis and also plays an important role in neuronal repair (31-33). It has been shown that apoE is mainly synthesized by astrocytes within which it is packaged with cholesterol and phospholipid to form lipid/protein complexes, which are then released into the extracellular space (34). These complexes bind to apoE receptors on the surfaces of nerve cells by which means they are internalized, thereby providing a mechanism for the maintenance and repair of cell membranes, the growth of neurites, and synaptogenesis (35).
A

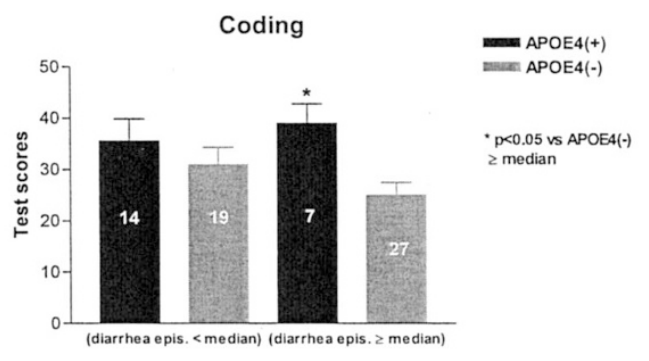

B

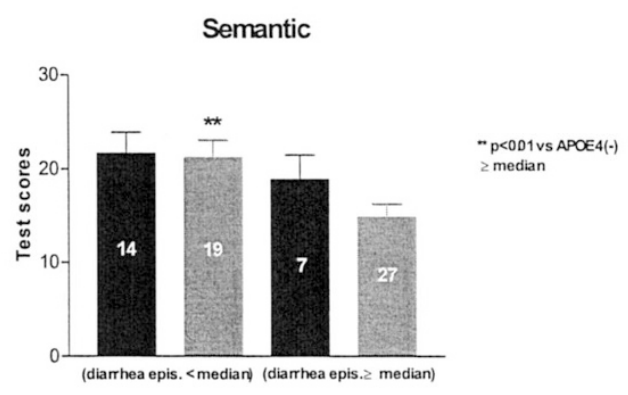

C

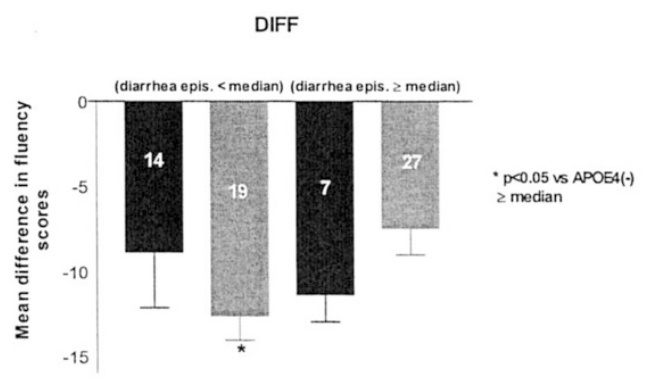

Figure 1. (A) APOE4-positive children performed significantly better in coding testing in the first $2 \mathrm{y}$ of life compared with APOE4-negative children under heavy burdens of diarrhea (greater than or equal to the median number of diarrhea episodes). (B) APOE4 also prevented the decline of semantic test scores and $(C)$ the mean difference in fluency scores (phonetic - semantic scores) observed in APOE4-negative children afflicted with similar heavy burdens of diarrhea in the first $2 \mathrm{y}$ of life greater than or equal to the median number of diarrhea episodes).

The formation of synaptic contacts is a critical phase during brain development and plays a crucial role in long-term synaptic plasticity in the adult CNS (36). CNS neurons produce enough cholesterol to survive and grow, but the formation of numerous mature synapses demands additional amounts that 
Table 3. Cognitive scores and allele 4 frequency

\begin{tabular}{|c|c|c|c|c|c|c|c|c|c|c|c|c|}
\hline \multirow[b]{2}{*}{ Cognitive profile } & \multicolumn{6}{|c|}{ Total study population } & \multicolumn{6}{|c|}{ Children with heavy burdens of diarrhea } \\
\hline & $\begin{array}{c}\operatorname{APOE} 4(+) \\
N(f \%)\end{array}$ & $\begin{array}{c}\mathrm{APOE} 4(-) \\
N(f \%)\end{array}$ & OR & $95 \% \mathrm{CI}$ & $p$ & $\chi^{2}$ & $\begin{array}{c}\mathrm{APOE} 4(+) \\
N(f \%)\end{array}$ & $\begin{array}{l}\mathrm{APOE} 4(-) \\
\quad N(f \%)\end{array}$ & OR & $95 \% \mathrm{CI}$ & $p$ & $\chi^{2}$ \\
\hline TONI III > median & $\begin{array}{c}11 \\
(20.4)\end{array}$ & $\begin{array}{c}43 \\
(79.6)\end{array}$ & 3.45 & $\begin{array}{c}1.02 \text { to } 11.61 \\
(16.6)\end{array}$ & $0.037 *$ & 4.34 & $\begin{array}{c}4 \\
(83.4)\end{array}$ & 20 & 0.28 & 0.06 to 1.58 & 0.19 & 2.15 \\
\hline TONI III $<$ median & $\begin{array}{c}04 \\
(6.9)\end{array}$ & $\begin{array}{c}54 \\
(93.1)\end{array}$ & & & & & $\begin{array}{c}2 \\
(5.2)\end{array}$ & $\begin{array}{c}36 \\
(94.8)\end{array}$ & & & & \\
\hline Semantic $>$ median & $\begin{array}{c}13 \\
(19.1)\end{array}$ & $\begin{array}{c}55 \\
(80.9)\end{array}$ & 2.28 & 0.81 to 6.43 & 0.111 & 2.52 & $\begin{array}{c}4 \\
(14.2)\end{array}$ & $\begin{array}{c}24 \\
(85.8)\end{array}$ & 0.16 & 0.02 to 1.56 & 0.15 & 3.08 \\
\hline Semantic $<$ median & $\begin{array}{c}06 \\
(9.4)\end{array}$ & $\begin{array}{c}58 \\
(90.6)\end{array}$ & & & & & $\begin{array}{c}1 \\
(2.6)\end{array}$ & $\begin{array}{c}37 \\
(97.4)\end{array}$ & & & & \\
\hline Phonetic $>$ median & $\begin{array}{c}12 \\
(18.8)\end{array}$ & $\begin{array}{c}52 \\
(81.2)\end{array}$ & 1.81 & 0.66 to 4.96 & 0.243 & 1.36 & $\begin{array}{c}4 \\
(12.5)\end{array}$ & $\begin{array}{c}28 \\
(87.5)\end{array}$ & 0.47 & 0.098 to 2.54 & 0.67 & 0.72 \\
\hline Phonetic $<$ median & $\begin{array}{c}07 \\
(11.3)\end{array}$ & $\begin{array}{c}55 \\
(88.7)\end{array}$ & & & & & $\begin{array}{c}2 \\
(6.2)\end{array}$ & $\begin{array}{c}30 \\
(93.8)\end{array}$ & & & & \\
\hline Total Fluency $>$ median & $\begin{array}{c}13 \\
(19.1)\end{array}$ & $\begin{array}{c}55 \\
(80.9)\end{array}$ & 1.71 & 0.65 to 4.45 & 0.267 & 1.23 & $\begin{array}{c}5 \\
(16.6)\end{array}$ & $\begin{array}{c}25 \\
(83.4)\end{array}$ & 0.29 & 0.069 to 1.59 & 0.23 & 2.10 \\
\hline Total Fluency $<$ median & $\begin{array}{c}08 \\
(12.1)\end{array}$ & $\begin{array}{c}58 \\
(87.9)\end{array}$ & & & & & $\begin{array}{c}2 \\
(5.5)\end{array}$ & $\begin{array}{c}34 \\
(94.5)\end{array}$ & & & & \\
\hline Coding $>$ median & $\begin{array}{c}15 \\
(22.1)\end{array}$ & $\begin{array}{c}53 \\
(77.9)\end{array}$ & 2.64 & 0.95 to 7.31 & 0.056 & 3.64 & $\begin{array}{c}7 \\
(20.5)\end{array}$ & $\begin{array}{c}27 \\
(79.5)\end{array}$ & 0.05 & 0.002 to 0.97 & $0.011^{*}$ & 7.69 \\
\hline Coding $<$ median & $\begin{array}{c}06 \\
(9.7)\end{array}$ & $\begin{array}{c}56 \\
(90.3)\end{array}$ & & & & & 0 & $\begin{array}{c}34 \\
(100)\end{array}$ & & & & \\
\hline Maze $>$ median & $\begin{array}{c}11 \\
(18.3)\end{array}$ & $\begin{array}{c}49 \\
(81.7)\end{array}$ & 1.17 & 0.44 to 3.08 & 0.748 & 0.10 & $\begin{array}{c}4 \\
(13.3)\end{array}$ & $\begin{array}{c}26 \\
(86.7)\end{array}$ & 0.54 & 0.09 to 3.232 & 0.67 & 0.46 \\
\hline Maze $<$ median & $\begin{array}{c}09 \\
(16.1)\end{array}$ & $\begin{array}{c}47 \\
(83.9)\end{array}$ & & & & & $\begin{array}{c}2 \\
(7.6)\end{array}$ & $\begin{array}{c}24 \\
(92.4)\end{array}$ & & & & \\
\hline
\end{tabular}

Abbreviations: OR, odds ratio; CI, confidence interval.

$* p<0.05$, after correction by Mantel-Haenszel.

must be provided by glia (37). Synthesis, transport, or uptake of cholesterol in the CNS may directly impact the development and plasticity of the synaptic circuitry. New lines of evidence indicate that cholesterol produced by glia cells and secreted in apoE-containing lipoproteins is the glial factor involved in regulation of synaptogenesis (38).

The APOE4 allele has been associated with an increased risk of cardiovascular disease and vascular atherogenesis by enhancing total plasma LDL cholesterol levels and has been defined as a genetic risk factor for developing late-onset Alzheimer's disease in most epidemiologic studies worldwide $(39,40)$. In addition, the allele $\epsilon 4$ has also been alleged to determine poor recovery followed traumatic brain injury $(1,2)$ and defective plasticity possibly due to a new gain-of-negative function due to a toxic insult in a dose-dependent manner (41). However, to date, few studies have addressed the allele $\epsilon 4$ impact on brain development and maturation. Recently, a new impetus in neurobiology research has suggested a protective effect of the allele $\epsilon 4$ during early development and embryogenesis $(42,43)$, supporting these preliminary findings in shantytown children with early childhood diarrheal illnesses. The better cognitive outcomes of APOE4-positive children with a history of severe diarrhea in the formative first $2 \mathrm{y}$ of life might be related to improved cholesterol absorption and delivery to developing neurons. Several studies have well documented the role of APOE polymorphism in regulating lipid profile even early in life, with children carrying the apoE4 phenotype showing higher absorption of dietary cholesterol than apoE3 children and greater TG, LDL-C, and apoB levels $(44,45)$, predominantly in children with lowest birth weights (46). In addition, total plasma cholesterol levels may be affected by heavy burdens of malnourishing diarrhea $(47,48)$. Although it is accepted that plasma cholesterol cannot cross the bloodbrain barrier even during early brain development (most of the brain cholesterol is synthesized in situ) (49), it is possible that during rapid burst of neonatal development, brain cholesterol content may be modulated by cholesterol blood levels by an indirect signal pathway in response to cholesterol ingestion, as suggested by Boleman and colleagues (50). In support of this hypothesis, APOE4-positive children in our population with heavy diarrhea burdens had more preserved cognitive skills. During infancy, TG and LDL levels tend to be higher among breast-fed subjects than in bottle feeders (51). However, we cannot attribute our observed cognitive enhancement only to breast-feeding, because breast-feeding time did not correlate with any cognitive tests in children carrying the APOE4 allele (data not shown). Yet, we cannot rule out the possibility that nutrient deprivation and oxidative stress possibly induced by heavy diarrhea burdens might cause subtle changes in bloodbrain barrier permeability (52).

Dietary cholesterol was shown to increase cortical density of apoE immunoreactive neurons in frontal and hippocampal cortex in the rabbit brain, which might be followed by increased lipid traffic and apoE-cholesterol remodeling (53). It is plausible to speculate that increased apoE expression may also enhance plasma cholesterol availability for the same human brain areas that are known to mature later during childhood and adolescence and also being the ones that show earliest signs of neurodegeneration (10). In addition, dietary cholesterol may also interfere with neural plasticity indirectly by affecting myelin gene expression (54). 
Based on our results, we speculate that APOE4 might protect against diarrhea burdens by shifting cholesterol from availability to the enteric pathogenic parasites to the developing brain. Most of the parasites, including G. lamblia, which has been suggested to deleteriously affect growth and cognitive outcomes in shantytown children $(20,54 a)$, are unable to synthesize cholesterol, relying on the host intestinal sources (55). In addition, most of these parasites use host cholesterol via receptor-mediated endocytosis, involving the LDL-receptor pathway $(56,57)$. APOE4 might interfere with LDL endocytosis or cholesterol translocation by the parasite, thus reducing their viability and improving infection. Better-designed and larger studies are warranted to test this hypothesis.

In our previous studies, we have identified a disproportional impairment in semantic fluency in shantytown children with heavier diarrhea illnesses in the first $2 \mathrm{y}$ of life (54a). In this study, paradoxically, we have documented a protective function of the allele $\epsilon 4$ in semantic fluency but not phonetic fluency, suggesting different roles of apoE4 during early development and aging. Furthermore, our findings with coding testing, a cognitive assessment usually associated with working memory but which might also require long-term semantic memory (58), reinforces the advantage of children carrying the APOE4 allele who are challenged by heavy diarrhea burdens to perform categorical and linguistic tasks.

On the other hand, APOE4 carriers would develop increased serum levels of LDL and hepatic lipid accumulation, downregulating LDL receptors in the liver and increasing competition for the receptor. Reduced fetal and neonatal growth would determine poor liver growth, additionally leading to downregulation of hepatic receptors, possibly intensified by hepatic programming of the receptor gene expression $(59,60)$. Therefore, despite early cognitive advantages, APOE4-positive children would be at greater risk for developing Alzheimer's disease and atherosclerosis later in life with increased caloric intake and little exercise during adulthood. Recently, findings from Moceri and colleagues (61) further reinforce the importance of early-life APOE gene-environmental associations and the risk for developing Alzheimer disease.

In summary, we have documented a potentially protective role of the APOE4 allele on cognitive development in shantytown children challenged by heavy burdens of early childhood diarrhea, possibly by increasing LDL cholesterol blood levels and by regulating LDL receptors in liver. Even though our findings provide support for the benefit of the allele $\epsilon 4$ during life-threatening diarrheal illnesses early in life, we acknowledge that this is a pilot study and that larger studies are needed. Nonetheless, we believe that this work will be critical for guiding novel research initiatives and more conclusive investigations to address how APOE polymorphisms may affect brain plasticity and synaptogenesis under environmental challenge. Further use of designs controlling for environmental factors and family-based pedigree analyses are now being planned to extend these preliminary findings.

Acknowledgments. The authors thank the Brazilian health workers and the children who participated in our study and their families. We also thank Eliza Coleman for technical assistance and Dr. Debra G.D. Leonard for helpful comments.

\section{REFERENCES}

1. Friedman G, Froom P, Sazbon L, Grinblatt I, Shochina M, Tsenter J, Babaey S, Yehuda B, Groswasser Z 1999 Apolipoprotein E-epsilon4 genotype predicts a poor outcome in survivors of traumatic brain injury. Neurology 52:244-248

2. Crawford FC, Vanderploeg RD, Freeman MJ, Singh S, Waisman M, Michaels L, Abdullah L, Warden D, Lipsky R, Salazar A, Mullan MJ 2002 APOE genotype influences acquisition and recall following traumatic brain injury. Neurology 58:1115-1118

3. Strittmatter WJ, Bova Hill C 2002 Molecular biology of apolipoprotein E. Curr Opin Lipidol 13:119-123

4. Mahley RW, Rall SC Jr 2000 Apolipoprotein E: far more than a lipid transport protein. Annu Rev Genomics Hum Genet 1:507-537

5. Ivanovic DM, Leiva BP, Perez HT, Inzunza NB, Almagia AF, Toro TD, Urrutia MS, Cervilla JO, Bosch EO 2000 Long-term effects of severe undernutrition during the first year of life on brain development and learning in Chilean high-school graduates. Nutrition 16:1056-1063

6. Mendez MA, Adair LS 1999 Severity and timing of stunting in the first two years of life affect performance on cognitive tests in late childhood. J Nutr 129:1555-1562

7. Morgane PJ, Mokler DJ, Galler JR 2002 Effects of prenatal protein malnutrition on the hippocampal formation. Neurosci Biobehav Rev 26:471

8. Zagon IS, McLaughlin PJ 1982 Comparative effects of postnatal undernutrition and methadone exposure on protein and nucleic acid contents of the brain and cerebellum in rats. Dev Neurosci 5:385-393

9. Andrade JP, Cadete-Leite A, Madeira MD, Paula-Barbosa MM 1991 Long-term low-protein diet reduces the number of hippocampal mossy fiber synapses. Exp Neurol 112:119-124

10. Rice D, Barone S Jr 2000 Critical periods of vulnerability for the developing nervous system: evidence from humans and animal models. Environ Health Perspect 108:511533

11. Almeida SS, Tonkiss J, Galler JR 1996 Malnutrition and reactivity to drugs acting in the central nervous system. Neurosci Biobehav Rev 20:389-402

12. Wauben IP, Wainwright PE 1999 The influence of neonatal nutrition on behavioral development: a critical appraisal. Nutr Rev 57:35-44

13. Gordon N 1997 Nutrition and cognitive function. Brain Dev 19:165-170

14. Guerrant DI, Moore SR, Lima AA, Patrick PD, Schorling JB, Guerrant RL 1999 Association of early childhood diarrhea and cryptosporidiosis with impaired physical fitness and cognitive function four-seven years later in a poor urban community in northeast Brazil. Am J Trop Med Hyg 61:707-713

15. Guerrant RL, Kosek M, Lima AA, Lorntz B, Guyatt HL 2002 Updating the DALYs for diarrhoeal disease. Trends Parasitol 18:191-193

16. Lima AA, Moore SR, Barboza MS Jr., Soares AM, Schleupner MA, Newman RD, Sears CL, Nataro JP, Fedorko DP, Wuhib T, Schorling JB, Guerrant RL 2000 Persistent diarrhea signals a critical period of increased diarrhea burdens and nutritional shortfalls: a prospective cohort study among children in northeastern Brazil. J Infect Dis 181:1643-1651

17. Moore SR, Lima AA, Conaway MR, Schorling JB, Soares AM, Guerrant RL 2001 Early childhood diarrhoea and helminthiases associate with long-term linear growth faltering. Int J Epidemiol 30:1457-1464

18. Niehaus MD, Moore SR, Patrick PD, Derr LL, Lorntz B, Lima AA, Guerrant RL 2002 Early childhood diarrhea is associated with diminished cognitive function 4 to 7 years later in children in a northeast Brazilian shantytown. Am J Trop Med Hyg 66:590-593

19. Checkley W, Epstein LD, Gilman RH, Cabrera L, Black RE 2003 Effects of acute diarrhea on linear growth in Peruvian children. Am J Epidemiol 157:166-175

20. Berkman DS, Lescano AG, Gilman RH, Lopez SL, Black MM 2002 Effects of stunting, diarrhoeal disease, and parasitic infection during infancy on cognition in late childhood: a follow-up study. Lancet 359:564-571

21. Turic D, Fisher PJ, Plomin R, Owen MJ 2001 No association between apolipoprotein E polymorphisms and general cognitive ability in children. Neurosci Lett 299:97-100

22. Drewett R, Wolke D, Asefa M, Kaba M, Tessema F 2001 Malnutrition and mental development: is there a sensitive period? A nested case-control study. J Child Psychol Psychiatry 42:181-187

23. Zemel BS, Riley EM, Stallings VA 1997 Evaluation of methodology for nutritional assessment in children: anthropometry, body composition, and energy expenditure. Annu Rev Nutr 17:211-235

24. London SJ, Xia J, Lehman TA, Yang JH, Granada E, Chunhong L, Dubeau L, Li T, David-Beabes GL, Li Y 2001 Collection of buccal cell DNA in seventh-grade children using water and a toothbrush. Cancer Epidemiol Biomarkers Prev 10:12271230

25. Hixson JE, Vernier DT 1990 Restriction isotyping of human apolipoprotein E by gene amplification and cleavage with HhaI. J Lipid Res 31:545-548

26. Addya K, Wang YL, Leonard DG 1997 Optimization of apolipoprotein E genotyping. Mol Diagn 2:271-276

27. Souza DR, de Godoy MR, Hotta J, Tajara EH, Brandao AC, Pinheiro S Jr., Tognola WA, dos Santos JE 2003 Association of apolipoprotein E polymorphism in lateonset Alzheimer's disease and vascular dementia in Brazilians. Braz J Med Biol Res 36:919-923

28. Almeida OP, Shimokomaki CM 1997 Apolipoprotein E4 and Alzheimer's disease in Sao Paulo-Brazil. Arg Neuropsiquiatr 55:1-7 
29. de Andrade FM, Larrandaburu M, Callegari-Jacques SM, Gastaldo G, Hutz MH 2000 Association of apolipoprotein E polymorphism with plasma lipids and Alzheimer's disease in a Southern Brazilian population. Braz J Med Biol Res 33:529537

30. Cerhan JH, Ivnik RJ, Smith GE, Tangalos EC, Petersen RC, Boeve BF 2002 Diagnostic utility of letter fluency, category fluency, and fluency difference scores in Alzheimer's disease. Clin Neuropsychol 16:35-42

31. Graham DI, Horsburgh K, Nicoll JA, Teasdale GM 1999 Apolipoprotein E and the response of the brain to injury. Acta Neurochir Suppl (Wien) 73:89-92

32. Hung MC, Hayase K, Yoshida R, Sato M, Imaizumi K 2001 Cerebral protein kinase $\mathrm{C}$ and its mRNA level in apolipoprotein E- deficient mice. Life Sci 69:1419-1427

33. Reich EE, Montine KS, Gross MD, Roberts LJ II, Swift LL, Morrow JD, Montine TJ 2001 Interactions between apolipoprotein E gene and dietary alpha-tocophero influence cerebral oxidative damage in aged mice. J Neurosci 21:5993-5999

34. Ladu MJ, Reardon C, Van Eldik L, Fagan AM, Bu G, Holtzman D, Getz GS 2000 Lipoproteins in the central nervous system. Ann N Y Acad Sci 903:167-175

35. Poirier J, Baccichet A, Dea D, Gauthier S 1993 Cholesterol synthesis and lipoprotein reuptake during synaptic remodelling in hippocampus in adult rats. Neuroscience 55:81-90

36. Lagercrantz H, Ringstedt T 2001 Organization of the neuronal circuits in the centra nervous system during development. Acta Paediatr 90:707-715

37. Mauch DH, Nagler K, Schumacher S, Goritz C, Muller EC, Otto A, Pfrieger FW 2001 CNS synaptogenesis promoted by glia-derived cholesterol. Science 294:13541357

38. Goritz C, Mauch DH, Nagler K, Pfrieger FW 2002 Role of glia-derived cholestero in synaptogenesis: new revelations in the synapse-glia affair. J Physiol Paris 96:257263

39. Roses AD 1996 Apolipoprotein E alleles as risk factors in Alzheimer's disease Annu Rev Med 47:387-400

40. Corbo RM, Scacchi R 1999 Apolipoprotein E (APOE) allele distribution in the world. Is APOE*4 a 'thrifty' allele? Ann Hum Genet 63:301-310

41. Teter B, Xu PT, Gilbert JR, Roses AD, Galasko D, Cole GM 2002 Defective neuronal sprouting by human apolipoprotein E4 is a gain-of-negative function. J Neurosci Res 68:331-336

42. Zetterberg H, Palmer M, Ricksten A, Poirier J, Palmqvist L, Rymo L, Zafiropoulos A, Arvanitis DA, Spandidos DA, Blennow K 2002 Influence of the apolipoprotein E epsilon4 allele on human embryonic development. Neurosci Lett 324:189-192

43. Wright RO, Hu H, Silverman EK, Tsaih SW, Schwartz J, Bellinger D, Palazuelos E, Weiss ST, Hernandez-Avila M 2003 Apolipoprotein E genotype predicts 24-month bayley scales infant development score. Pediatr Res 54:819-825

44. Tammi A, Ronnemaa T, Viikari J, Jokinen E, Lapinleimu H, Ehnholm C, Simell O 2000 Apolipoprotein E4 phenotype increases non-fasting serum triglyceride concentration in infants - the STRIP study. Atherosclerosis 152:135-141

45. Herrmann W, Hanf S, Kaffarnik H, Motzny S, Reissner J, Steinmetz A 1994 The influence of apolipoprotein E polymorphism on plasma concentrations of apolipoprotein B and A-I during the first year of life. Pediatrics 93:296-302
46. Garces C, Benavente M, Ortega H, Rubio R, Lasuncion MA, Rodriguez ArtalejoF, Fernandez Pardo J, de Oya M 2002 Influence of birth weight on the apo E genetic determinants of plasma lipid levels in children. Pediatr Res 52:873-878

47. Houssaini FZ, Foulon T, Iraqi MR, Payen N, Groslambert P 1999 Lipids, lipoproteins, and fatty acids during infantile marasmus in the Fes area of Morocco. Biomed Pharmacother 53:278-283

48. Etukudo MH, Agbedana EO, Akinyinka OO, Osifo BO 1999 Plasma electrolytes, total cholesterol, liver enzymes, and selected antioxidant status in protein energy malnutrition. Afr J Med Med Sci 28:81-85

49. Dietschy JM, Turley SD 2001 Cholesterol metabolism in the brain. Curr Opin Lipidol 12:105-112

50. Boleman SL, Graf TL, Mersmann HJ, Su DR, Krook LP, Savell JW, Park YW, Pond WG 1998 Pigs fed cholesterol neonatally have increased cerebrum cholesterol as young adults. J Nutr 128:2498-2504

51. Owen CG, Whincup PH, Odoki K, Gilg JA, Cook DG 2002 Infant feeding and blood cholesterol: a study in adolescents and a systematic review. Pediatrics 110:597-608

52. Noseworthy MD, Bray TM 1998 Effect of oxidative stress on brain damage detected by MRI and in vivo 31P-NMR. Free Radic Biol Med 24:942-951

53. Sparks DL, Liu H, Gross DR, Scheff SW 1995 Increased density of cortical apolipoprotein E immunoreactive neurons in rabbit brain after dietary administration of cholesterol. Neurosci Lett 187:142-144

54. Salvati S, Attorri L, Avellino C, Di Biase A, Sanchez M 2002 Dietary prenatal lipids affect myelin gene expression in postnatal undernourished rats. Nutr Neurosci 5:243250

54a. Patrick PD, Oria RB, Madhaven V, Pinkerton RC, Lorntz B, Lima AA, Guerrant RL 2005 Limitations in verbal fluency following heavy burdens of early childhood diarrhea in Brazilian shantytown children. Child Neuropsychol, in press

55. Lujan HD, Mowatt MR, Byrd LG, Nash TE 1996 Cholesterol starvation induces differentiation of the intestinal parasite Giardia lamblia. Proc Natl Acad Sci U S A 93:7628-7633

56. Das S, Stevens T, Castillo C, Villasenor A, Arredondo H, Reddy K 2002 Lipid metabolism in mucous-dwelling amitochondriate protozoa. Int J Parasitol 32:655-675

57. Stevens TL, Gibson GR, Adam R, Maier J, Allison-Ennis M, Das S 1997 Uptake and cellular localization of exogenous lipids by Giardia lamblia, a primitive eukaryote. Exp Parasitol 86:133-143

58. Greenwald AG, Abrams RL, Naccache L, Dehaene S 2003 Long-term semantic memory versus contextual memory in unconscious number processing. J Exp Psychol Learn Mem Cogn 29:235-247

59. Hardy SC, Kleinman RE 1994 Fat and cholesterol in the diet of infants and young children: implications for growth, development, and long-term health. J Pediatr 125:S69-S77

60. Barker DJ, Martyn CN, Osmond C, Hales CN, Fall CH 1993 Growth in utero and serum cholesterol concentrations in adult life. BMJ 307:1524-1527

61. Moceri VM, Kukull WA, Emanuel I, van Belle G, Larson EB 2000 Early-life risk factors and the development of Alzheimer's disease. Neurology 54:415-420 